\title{
Exploring the influence of vegetation cover, sediment storage capacity and channel dimensions on stone check dam conditions and effectiveness in a large regulated river in México
}

\author{
Manuel Esteban Lucas-Borja ${ }^{\mathrm{a}, *}$, Demetrio Antonio Zema ${ }^{\mathrm{b}}$, Marco Daniel Hinojosa Guzman ${ }^{\mathrm{c}}$, \\ Yu Yang ${ }^{\mathrm{d}}$, Alejandro Cruz Hernández ${ }^{\mathrm{c}}$, Xu Xiangzhou ${ }^{\mathrm{e}}$, Bruno Gianmarco Carrà ${ }^{\mathrm{b}}$, Mary Nichols , $^{\mathrm{f}}$ \\ Artemio Cerdág \\ ${ }^{a}$ Departamento de Ciencia y Tecnología Agroforestal y Genética, Universidad de Castilla La Mancha, Campus Universitario s/n, E-02071 Albacete, Spain \\ b Department "Agraria", University "Mediterranea" of Reggio Calabria, Località Feo di Vito, I-89122 Reggio Calabria, Italy \\ ${ }^{c}$ Fábricas del Agua del Centro de Sinaloa, I.A.P. Blvd. Emiliano Zapata No. 2014-Int. B Pte. Col. Vallado Nuevo, 80110 Culiacán, Mexico \\ ${ }^{\mathrm{d}}$ Department of Sediment Research, China Institute of Water Resources and Hydropower Research, Beijing 100048, China \\ e School of Hydraulic Engineering, Dalian University of Technology, Dalian 116024, China \\ ${ }^{\mathrm{f}}$ Southwest Watershed Research Center, USDA-ARS, 2000 E. Allen Rd., Tucson, AZ, USA \\ ${ }^{\mathrm{g}}$ Soil Erosion and Degradation Research Group. Department of Geografia, University of Valencia, Blasco Ibànez, 28, E-46010 Valencia, Spain
}

\section{A R T I C L E I N F O}

\section{Keywords:}

Vegetation cover

Watershed management

Check dam failure

Sediment wedge

Soil erosion

\begin{abstract}
A B S T R A C T
Check dams are widely used for soil conservation at the watershed scale. When structurally sound, these engineering control works retain sediment as planned. However, there is limited information describing the influence of site characteristics on post-construction condition including structural stability and sediment retention capacity. More specifically, the effects of channel morphology, check dam geometry and vegetation characteristics as potentially influencing factors on sediment retention capacity at the watershed level are poorly understood. Thus, an investigation applying field and remotely sensed measurements, multi-regression models, redundancy and sensitivity analysis, and correlation analysis was conducted in a Mexican watershed where the characteristics of 273 check dams were evaluated 3-5 years after construction. Vegetation cover and dimensions of the channel were found to be the most important factors influencing check dam fate. Taller structures experienced the greatest failure risk, in contrast to lower and wider structures and associated vegetation cover that retained long and wide sediment wedges, which helped to stabilise the check dams. The potential sediment storage capacity of the check dams mainly depends on the downstream height of the structure, but also on the vegetation cover near the structure walls; check dams constructed across a range of channel dimensions are able to effectively store sediment. Overall, this study provides a quantitative evaluation of the dominant factors influencing the post-construction conditions of check dams and their ability to store sediment, and thus provides land managers insights into the best strategies for soil conservation at the watershed scale using check dams.
\end{abstract}

\section{Introduction}

Check dams are made of various materials, including concrete blocks, loose stones, rocks in gabion baskets, or wood, and they can be identified as a small barriers built across a drainage channel to control runoff and sediment transport, and enhance sedimentation (Nyssen et al., 2004). These stream control works are widely used around the world, often as one component of watershed scale efforts to control runoff, erosion, and sediment transfers (Mekonnen et al., 2015; Quiñonero et al., 2016). They often have been installed throughout drainage networks covering extensive regions. For instance in torrents of Calabria (Southern Italy), where up to 6 check-dams per $\mathrm{km}^{2}$ (Bombino et al., 2007) were installed, more than $75 \%$ of the hydrographic network has been treated. Guyassa et al. (2017) report extensive installation of check dams during the last three decades in gullies of the Highlands of Northern Ethiopia as soil and water conservation practices. In ephemeral channels of southeast Spain, check dams were used to stabilize hillslopes by inducing deposition and forming flat sediment wedges that reduce runoff slopes (Conesa Garcia and Garcia Lorenzo, 2010). In addition to their use in soil conservation,

\footnotetext{
* Corresponding author.

E-mail address: ManuelEsteban.Lucas@uclm.es (M.E. Lucas-Borja).
} 


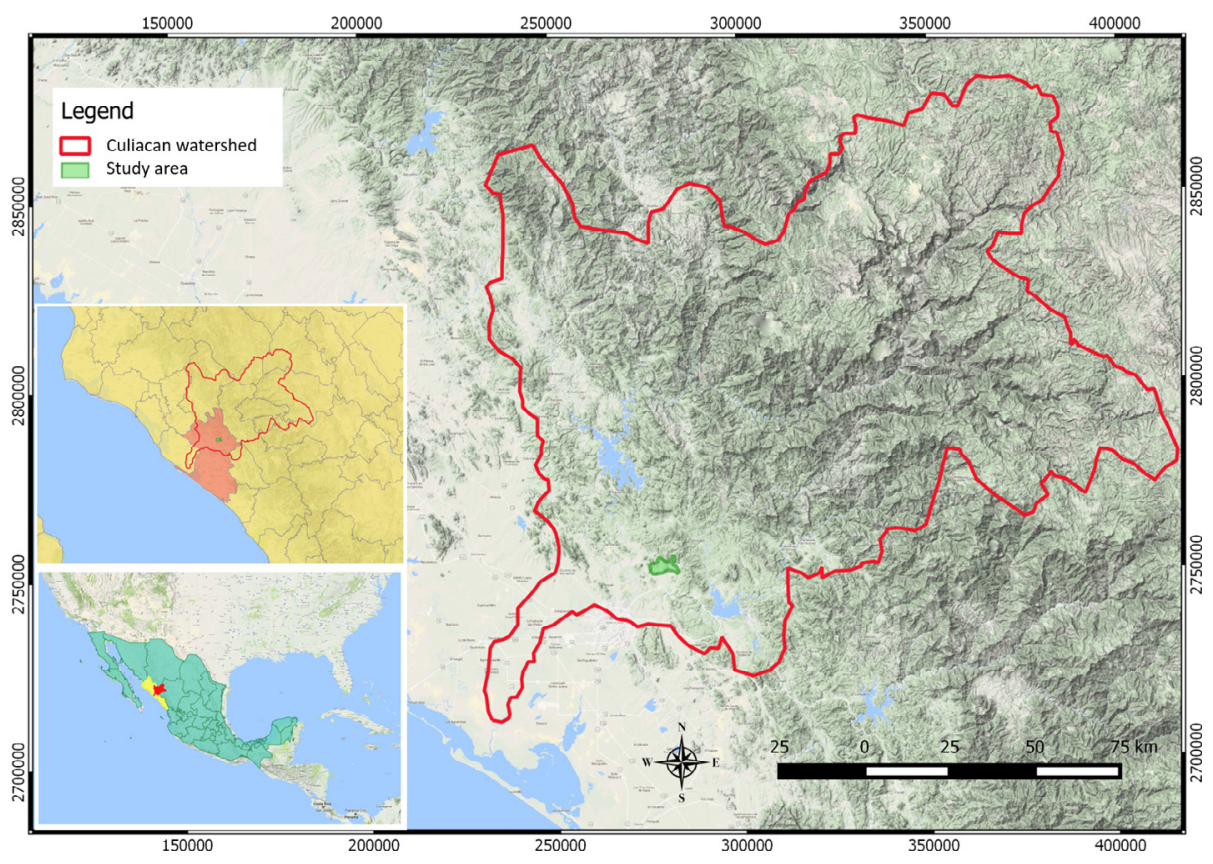

Fig. 1. Geographic location of the stone check dams investigated in the Culiacan watershed (Mexico).

check dams have been constructed in gullies to retain sediment and form farmland in Loess Plateau in China (Xu et al., 2004).

Check dams, which are usually build to control water and sediment fluxes along stream channels (e.g. Heede, 1978; Nyssen et al., 2004) also exert important effects on channel morphology, bed sediment and vegetation (Conesa Garcia and Garcia Lorenzo, 2010; Xu et al., 2004; Boix-Fayos et al., 2007; Zema et al., 2014, 2018). In the Mediterranean environment of southern Italy, Bombino et al. (2009) showed the positive effects of check dams on headwater mountain channels affecting both physical adjustments and the extent and development of riparian vegetation. Boix-Fayos et al. (2007) evaluated the effects of check dams on river channel morphology in Spain and found that after 30 years, most of the check dams lost much of their trap efficiency, and erosion of the alluvial deposits upstream of check dam had begun. Xu et al. (2012) performed a series of calculations to quantify the effects of conservation managements in terms of retaining soil, water, and especially nutrients 50 years after implementation in a representative catchment on the Loess Plateau (China). This research resulted in recommendations of preferred conservation practice in the area. An evaluation of check dams constructed in two small semi-arid watersheds in the south-western United States revealed that check dam failures were minimal, however loss of sediment retention capacity was rapid, within seven years, due to high sediment loads (Polyakov et al., 2014; Nichols et al., 2016). Nyssen et al. (2004) reported that soils influenced the rate of check dam failures with higher rates in areas with smectite-rich soils that are prone to swelling. However, although check dams are widely used as a watershed management tool, often in combination with complimentary engineering works, for enhancing watershed and grade stabilization and their impacts have been investigated in various ecosystems, information describing and quantifying the watershed factors affecting check dam stability and efficacy is limited.

From the previous examples, it appears that after construction, one of the most important features influencing the effectiveness of check dams on the watershed system is their sediment storage capacity. Storage capacity is directly related to structural condition, but the efficacy of check dams is also related to biotic and abiotic factors, such as channel geometry, land use, soil type, and vegetation cover. In particular, the scientific literature has evidenced the basic role of vegetative cover for an ecologically sound regulation activity of rivers (e.g. Gurnell and Petts, 2002, 2006; Allmendinger et al., 2005; Corenblit et al.,
2007). In our study, we hypothesised that, vegetation cover percentage and type may significantly influence sediment transfer and channel deposition, which in turn affects check dam stability and failure. We expect that lower vegetation cover will result in higher sediment transfers and thus the likelihood of stone check dam failure will increase. Therefore, in view of an integrated management of regulated watersheds, there is a need to investigate which of the factors mentioned above are the most influencing on both the condition of check dam structures and their ability to store sediment with particular stress on the role of the vegetation cover. This information is important to maximize the likelihood of successful conservation works. Failure to account for high intensity rainstorms, upstream areas with highly erodible soils, absence of vegetation cover in the watershed, inadequate channel dimensions for a check dams installation or steeped channels may generate high quantities of sediment transfer and drawing attention to the risks posed by these structures as they fill with sediment and deteriorate (Wang et al. 2009). Check dams failure and the sudden or gradual erosion of previously deposited sediment can reintroduce large quantities of sediment for subsequent transport (Brooks and Lawrence 1999).

To address these issues, a large regulated watershed in Mexico is presented as a case study. Here, more than 250 check dams, recently built to slow runoff and retain sediment, are intact, but many other structures have failed. A large dataset describing the condition and functioning of the check dams was compiled and reported by Cruz Hernandez et al. (2014). This dataset is combined with remotely sensed data to interpret possible cause-effect relationships between sub-watershed characteristics and the structural condition and functioning (in terms of sediment storage capacity) of the check dams. Specifically, a combination of analytical techniques (stepwise regression, redundancy analysis, increase-rate-analysis and correlation analysis) to the check dam dataset collected in the watershed. The subsequent interpretation identifies and quantifies the most influential watershed factors (channel dimensions, vegetation cover, characteristics of the check dams and others) affecting both the structural condition and functioning of check dams; finally, the role of the vegetation is focussed as a co-factor synergetic with the actions of check dams towards ecologically sound regulation of the studied river. 


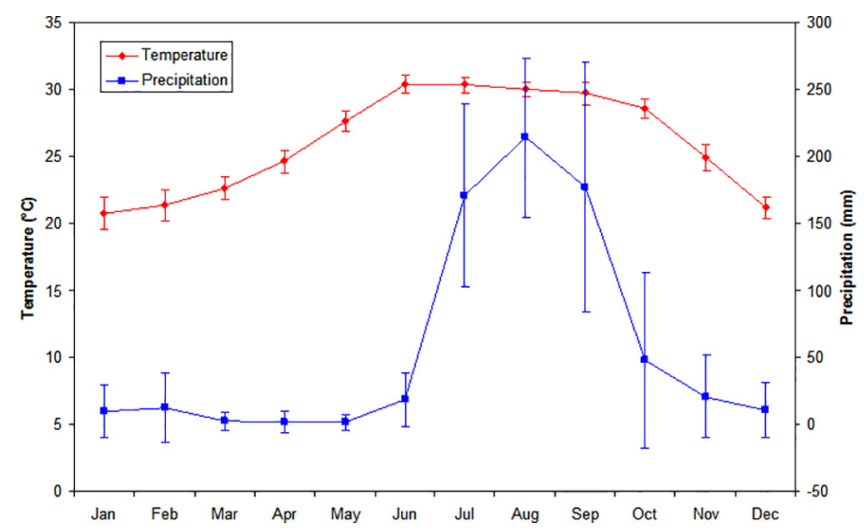

Fig. 2. Annual trends (mean \pm std. dev.) of precipitation and mean temperature measured at the meteorological station of Culiacàn in the period 1995-2015.

\section{Materials and methods}

\subsection{Study area}

This study was conducted in the Culiacan watershed in the state of Sinaloa, north-western Mexico (latitude $24.867346^{\circ} \mathrm{N}$, longitude $-107.181013^{\circ} \mathrm{W}$ ) (Fig. 1). The watershed, which covers $10,368 \mathrm{~km}^{2}$, drains into the Sinaloa reservoir at an elevation of $128 \mathrm{~m}$ after running $25.3 \mathrm{~km}$ from the headwater. Topography ranges from mountains to lower lying hilly areas and plains. Average annual precipitation is $860 \mathrm{~mm}$, mostly occurring, together with the resulting surface runoff, during July, August and September; winters are generally milder and in this season rainfall is less intense. Mean annual temperatures are in the range $24-26^{\circ} \mathrm{C}$. Fig. 2 reports the annual trends of precipitation and mean temperature measured at the Culiacàn meteorological station during the period 1995-2015.

Main land uses are cropland (sorghum and corn), covering $44.2 \%$ of the total watershed area, protective forest and grazing, $46.7 \%$ and $0.3 \%$ of the area, respectively. Typical vegetation consists of medium-statured tropical forest (including semi-evergreen forest, sub-deciduous forests, and riparian forests), Pinus-Quercus forest, spiny forest; gallery forest (includes "selva mediana ribereña"), tropical dry forest (PérezGarcía et al., 2012). Geology is representative of Jurassic to Quaternary periods, while, according to FAO, 1988, soils of the study area can be classified as Eutric regosols and haplic Feozem. The drainage patterns of the watershed are controlled by the low relief and surface runoff resulting in a trellis pattern that has produced numerous ephemeral channels. Artificial cut-offs or bank protection were not constructed to reduce lateral migration.

In this watershed, small, temporary, stone check dams were constructed across swales and drainage ditches (Figs. 3 and 4). These structures were built to reduce flow velocity and thereby potentially

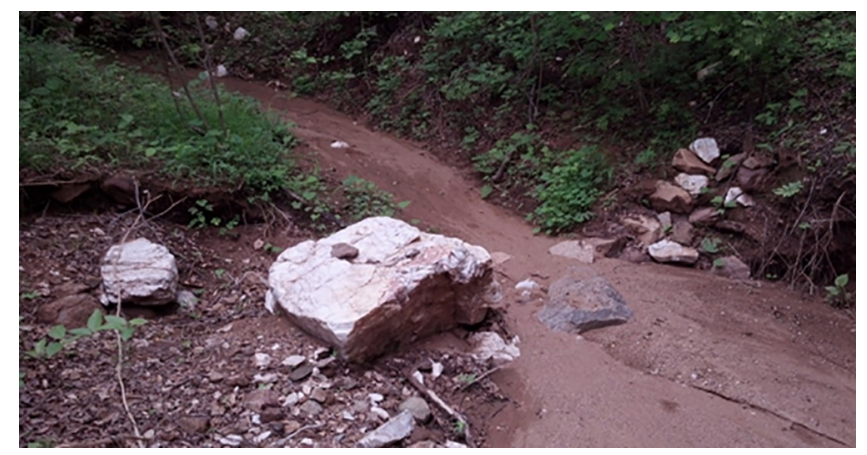

Fig. 3. Stone check dam failure (broken) in the Culiacan watershed (Mexico).

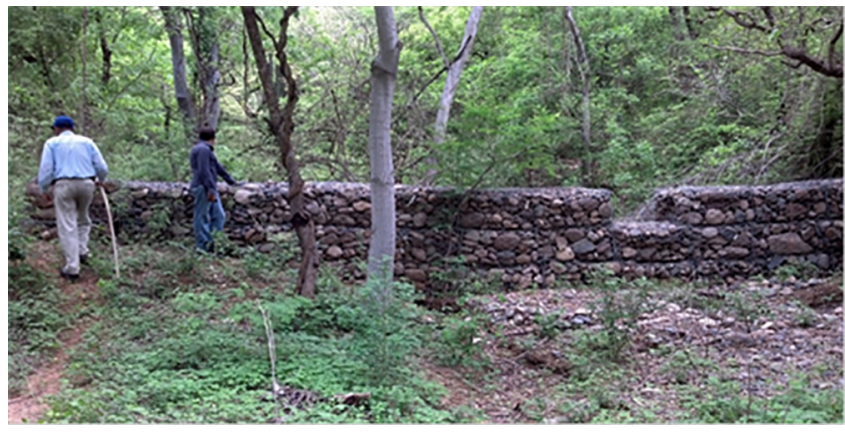

Fig. 4. A working gabion check dam in the Culiacan watershed (Mexico).

control the channel grade and mitigate channel erosion. The maximum height of the stone check dams is $3 \mathrm{~m}$; to increase their stability, the base of each check dams is embedded into the soil approximately at 1meter depth. The check dams were constructed to achieve complete cover of the channel and to assure that the middle of the dam is lower than the edges. No large magnitude, low frequency floods were recorded during the period of study (2011-2015). Fig. 5 shows a general map and the original/regulated longitudinal profile of of four reaches containing the staggered check dams, allowing the identification of the channel gradient changes following the structure installation.

\subsection{Survey methods}

The studied stone check dams were regularly evaluated from 2011 to 2015 to assess their effectiveness and impact on channel adjustments, sediment storage, and vegetation dynamics. The structures were built as part of an "emergency" strategy aiming to retain water and sediment fluxes generated by rainstorms on upstream areas with highly erodible soils; thus it is expected that these control works start functioning immediately after their installation and a short-term monitoring activity can assure these requirements.

This study was carried out by using a combination of fieldwork and analysis of remotely sensed data. Field surveys were made by Cruz Hernandez et al. (2014) to analyse the operating condition of each check dam. During these surveys, structure dimensions and both upstream and downstream channel morphology were quantified through measurements (Fig. 6) using standard topographic surveying equipment and laser technology (measurements up to $75 \mathrm{~m}$, accuracy $\pm 3 \mathrm{~mm}$ ). Field data included both categorical and continuous variables. Categorical data for the stone check dams were type (gabion and stone check dams); year of construction (from 2011 to 2015, drawn from check dam design or construction reports available at managing authorities); current operational condition ("functional", i.e. operating as designed, "filled", by sediment or "broken", that is, completely collapsed and thus not functioning); location (low, between 59 and $104 \mathrm{~m}$ a.s.l., middle, $107-153 \mathrm{~m}$, or upper watershed, $154-200 \mathrm{~m}$ ); structure (gabions or unembedded stones). The continuous variables surveyed include check dam location (X, Y UTM coordinates): check dam dimensions (length, width and downstream height, in metres, see also Fig. 6); longitudinal slope of the channel (\%, measured as the difference between the heights of the channel and check dam divided by the channel length); potential storage capacity $\left(\mathrm{m}^{3}\right)$; actual sediment storage $\left(\mathrm{m}^{3}\right)$; ratio actual sediment storage/potential storage capacity (\%) (see below); channel dimensions associated with each check dam (m). During topographic surveys, the channel elevation was measured upstream of each check dam at a longitudinal step of 5-10 m, in order to define the longitudinal profile of the regulated channel. The original channel profile was estimated from the last available digital terrain models created before the check dam construction (resolution of $1 \times 1$ metres, years 2010-11) or, when available, from the check dam designs. The two reconstructed longitudinal profiles allowed reconstructing the sediment wedge dimensions 

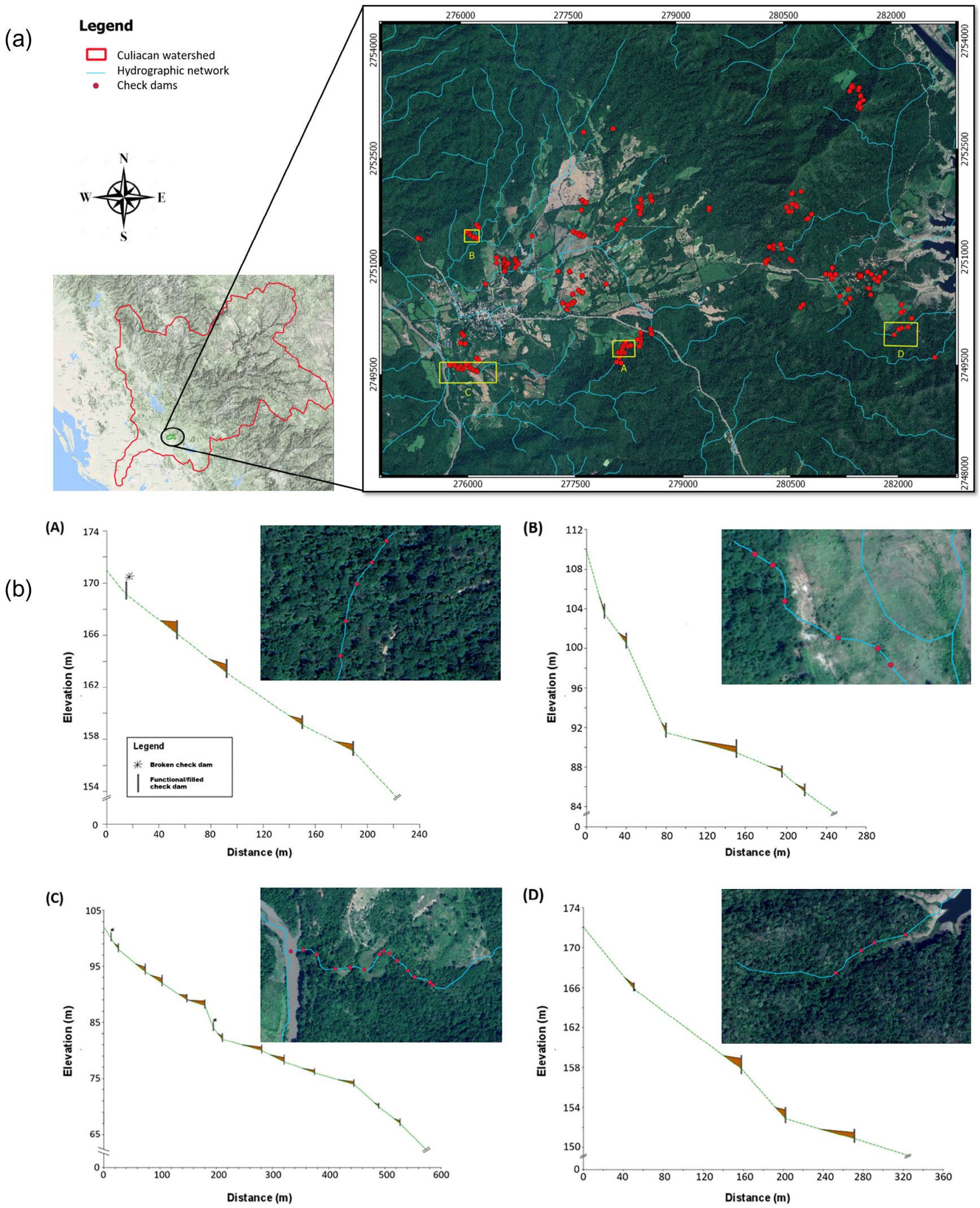

Fig. 5. Map (a) as well as longitudinal original and regulated profiles (b) of four check dam staggered series in the Culiacan watershed (Mexico).

and estimating the local slope behind each check dam (Figs. 5 and 6).

From the current (regulated) and the original longitudinal profiles close to the check dams as well as from check dam dimensions, the potential storage capacity and actual sediment storage were estimated assuming that the deposited sediment volume behind a check dam has a prismatic shape with a trapezoidal section (Castillo et al., 2007; RamosDiez et al., 2016a,b; 2017a). The surveyed channel dimensions include upstream/downstream depth (measured at the check dam location); 

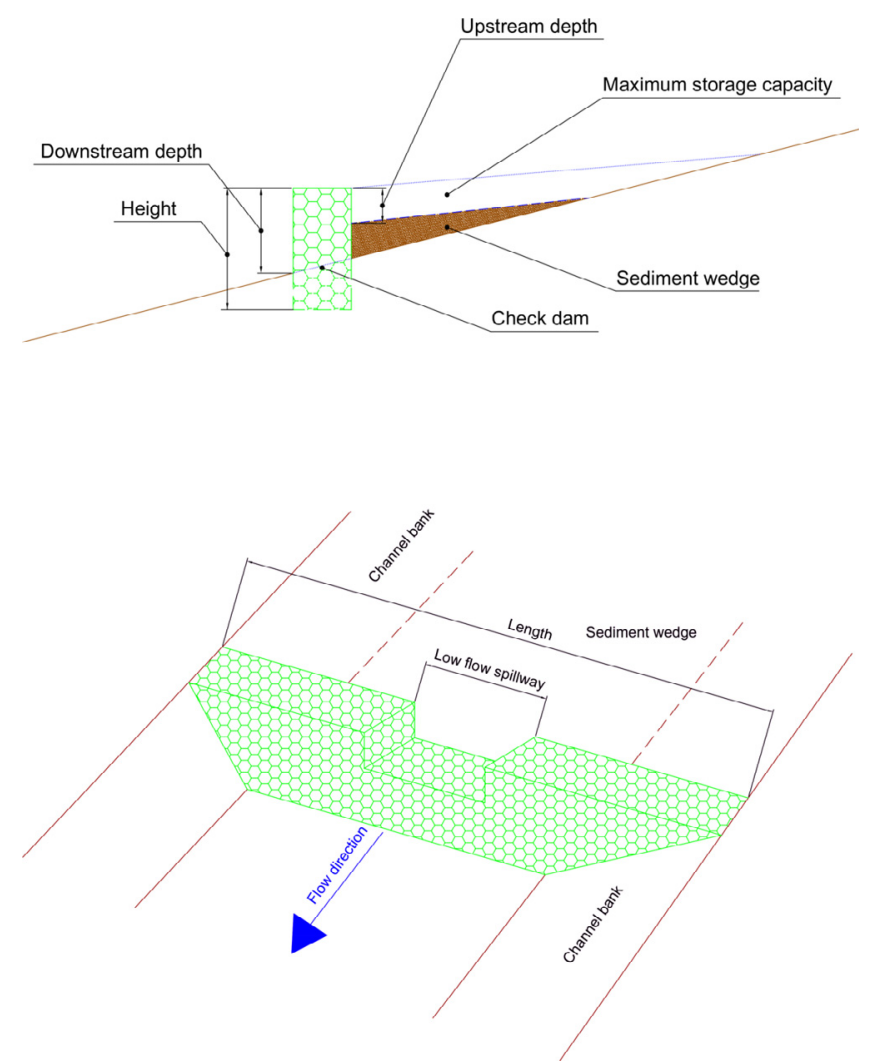

Fig. 6. Annotated schematic showing side and oblique views of a typical stone check dam in the Culiacan watershed (Mexico).

length; average width (measured every $5 \mathrm{~m}$ starting immediately upstream of the check dam until the check dam located immediately upstream or, for the first structure, the watershed perimeter).

Remotely sensed data was used to quantify watershed characteristics such as vegetation cover and soils. More in detail, vegetation cover of the sub-watershed (\% of area, estimated by maps produced by remotely sensed data); soil type and land use (forest or crop, analysed separately for each of the sub-watershed in which the main basin was discretised) for each reach/sub-watershed was derived from GIS analyses and satellite images (Landsat 8 source data at $30-\mathrm{m}$ resolution and Rapideye images at 5-m resolution). Watershed morphometric information was delineated from DEM (at 1-m resolution) which was firstly georeferenced and then processed by a GIS software. This processing allowed identifying the hydrographic network and 273 subwatersheds/reaches (each one containing a check dam); more specifically, each check dam was associated to a reach and considered its outlet: this latter drains a sub-watershed (part of the entire watershed) conveying water to the reach. Check dams were located on the watershed map according to their geographical coordinates drawn from satellite images (where the structures were visible) or from the topographic survey.

\subsection{Analytical methods}

The collected data were processed by a combination of four analytical techniques: (i) linear correlation analysis; (ii) stepwise regression analysis; (iii) redundancy analysis (RDA); (iv) increase-rate-analysis (IRA). Firstly, in order to identify possible mathematical structures among vegetation cover, sediment storage capacity and channel dimensions and to determine the related correlation coefficients, the Spearman correlation matrix was computed based on the current values of the variables surveyed for the sampled check dams. Preliminarily, the indicators were standardised by converting data to zero mean and unit variance.

Then, stepwise regression analysis was used to build an optimized mathematical model relating the response (dependent) variable (in our case the current operational condition of check dams) to the explanatory (independent) factors (the remaining categorical and continuous variables). Stepwise regression is a type of multiple linear regression which can choose the best-fitted combination of explanatory variables for response variable predication with forward-adding and backward-deleting variables. The stepping procedure begins as an initial model definition with a stepped forward addition of a variable to the previous model. The critical $\mathrm{F}$ value is then used to check the eligibility of the added variable. With a new variable added, the previous variables in the model may lose their predictive ability. Thus, stepping criteria are used to check the significance of all the included variables. Based on this situation, the significant variables could be confirmed. While, if the variable is insignificant, then the backward method is used to delete it. Forward adding and backward deleting are repeated until no variable is added or removed. The stepping procedure is eliminated when the optimized model is constructed. The stepping criteria were used to check the significance (at $p=0.05$ ) of all the included variables. The procedure was stopped when the optimized model was built and the maximum $\mathrm{r}^{2}$ between response variable and explanatory factors was achieved.

RDA was used with the main focus on the relationships between the check dam conditions (functional, filled or broken) and those factors influencing it (selected by stepwise regression). The check dam conditions were response variables in this analyses, whereas the explanatory variables selected according to the stepwise regression belongs to the three categories (check dams characteristics, check dam volume and channel dimensions): therefore, the explanatory variables included the selected significant variables that could represented each categories. In order to explore the factors affecting check dam conditions comprehensively, the raw data were standardized before the RDA analyses, and the significance of the variables was tested with Monte Carlo simulations. All the above analyses were performed with $\mathrm{R}$ software version 3.2.0 (R Core Team 2013), with the main aim of a quantitative expression of the explanatory factors on check dam conditions.

A revised IRA (Xu et al., 2015) was used to evaluate the variation in the ratio of the actual sediment storage (henceforth, ASS) to the potential storage capacity (PSC) of check dams, with respect to changes in the significant explanatory variables (considered as causal factors). This ratio (that is, ASS/PSC) is equal to the sediment filling degree (SFD, in $\%$ ) of a check dam. Specifically, ASS is the volume $\left(\mathrm{m}^{3}\right)$ of the actual sediment wedge behind a check dam, while PSC is the volume $\left(\mathrm{m}^{3}\right)$ that the sediment wedge would have, if the check dam was entirely filled with sediments. Therefore, a filled check dam shows a SFD equal to $100 \%$ (ASS $=$ PSC), for an empty structure SFD $=0$, while a functional structure has a SFD between 0 and $100 \%(0<$ ASS $<$ PSC). In the first case, the check dam is not able to retain more sediment in the future, being its capacity completely depleted.

In order to carry out a sensitivity analysis, all dams were ordered according to the amount of potential storage capacity from the largest to the smallest. The difference in SFD between two successively ordered check dams ( $i$ and $i-1), R P_{\mathrm{i}}(\%)$, was calculated as follows:

$R P_{i}=\frac{2\left(S F D_{i}-S F D_{i-1}\right)}{S F D_{i}+S F D_{i-1}}$

where $P_{i}$ is the SFD (\%) of the i-th check dam.

As reported in details by Xu et al. (2015), the Absolute Sensitivity Parameter (S), $S_{\mathrm{j}}$, towards an explanatory variable $t$ is calculated by its mean growth rate:

$S_{\mathrm{j}}={\overline{\left(R P_{\mathrm{i}, \mathrm{j}} / R t_{\mathrm{i}, \mathrm{j}}\right)_{\mathrm{i}=1, \mathrm{~N}}}}$

being $j$ the $\mathrm{j}$-th explanatory variable, $\mathrm{N}$ the total number of check dams and: 
$R t_{\mathrm{i}}=\frac{2\left(t_{\mathrm{i}}-t_{\mathrm{i}-1}\right)}{t_{\mathrm{i}}+t_{\mathrm{i}-1}}$

$R t_{\mathrm{i}}$ is the increase rate calculated for two successively ordered check dams ( $i$ and $i-1$ ), where $t$ is the value of the explanatory variable. Finally, the Relative Sensitivity Parameter (s) of the j-th explanatory variable $t_{\mathrm{j}}, s_{\mathrm{j}}$, which can be used to qualitatively evaluate the effect of the explanatory variable $t$ on $s$ was calculated as follows:

$S_{\mathrm{j}}=\frac{S_{\mathrm{j}}}{\min \left(\left|S_{\mathrm{j}}\right|\right)_{\mathrm{j}=1, \mathrm{M}}}$

where $\mathrm{M}$ is the total number of the explanatory variables.

In our study, we calculated the Absolute and Relative Sensitivity Parameters of SFD (henceforth, $\mathrm{S}_{\mathrm{SFD}}$ and $\mathrm{S}_{\mathrm{SFD}}$ ); as explanatory variables of $S_{S F D}$ and $S_{S F D}$, vegetation cover, longitudinal slope, channel depths (measured immediately from the downstream and the upstream of a check dam) as well as length and width of the channel (equal to that of the check dam) were considered.

\section{Results}

The results show that the potential storage capacity of the studied stone check dams ranged from 0.5 to $493.5 \mathrm{~m}^{3}$, with a mean value of $51.5 \mathrm{~m}^{3}$. The actual volume of sediment stored upstream of the check dams ranged from 0.2 to $237.6 \mathrm{~m}^{3}$ with a mean value of $26.7 \mathrm{~m}^{3}$. The average width of the upstream sediment wedge was $6.5 \mathrm{~m}$, ranging from 2.4 to $22.5 \mathrm{~m}$. The mean downstream depth of the stone check dams was $1.1 \mathrm{~m}$, ranging to 0.1 to $1.9 \mathrm{~m}$. Finally, the length of the sediment wedge stored upstream ranged $\mathrm{m}$ to 3.9 to $39.1 \mathrm{~m}$, with a mean value of $13.8 \mathrm{~m}$.

Of the 273 analysed check dams, 116 (43\%) are operating as designed and thus currently regulate water and sediment flows inside the watershed. They are classified as functional. Seventy-four of the check dams (27\%) show a compromised structure (that is, they have lost their functionality, because they have collapsed) and they are classified as broken; and $83(30 \%)$ are classified as filled, showing thus a totally full upstream wedge, and presumably the equilibrium channel slope has been reached. On average, the functional check dams were filled to $45 \%$ of their storage capacity, and thus have the capacity to retain additional sediment (Table 1).

The average longitudinal channel slope among all evaluated check dams was quite similar (ranging from 6.53 to $7.68 \%$ ). In general, channel profiles were steepest upstream of filled check dams $(7.68 \%)$ and shallower upstream of functional (6.66\%) and broken $(6.53 \%)$ structures. The impact of sub-watershed vegetation cover in the immediate vicinity of the investigated control works was clear. In subwatersheds where the vegetation cover is high (45-53\%), fewer check dams were broken in comparison to those check dams in sub-watersheds where vegetation cover was low (13\%) (Table 1).

Results of the stepwise regression showed that six of the categorical and continuous independent variables were significant in explaining the variability in check dam condition ( $\mathrm{p}<0.05$ ) (Table 2), and there
Table 2

Best-fit combination of explanatory variables for check dam conditions as response variable using stepwise regression analysis applied to check dam data in Culiacan watershed (Mexico).

\begin{tabular}{lllll}
\hline Explanatory variables & Estimate & Std. Error & F-value & $\operatorname{Pr}(>|\mathrm{t}|)$ \\
\hline Vegetation cover & 0.070 & 0.030 & 30.34 & $<0.001$ \\
Potential storage capacity & 0.001 & 0.000 & 2.06 & 0.04 \\
Actual sediment storage & 1.760 & 0.030 & 3.19 & 0.002 \\
Channel length & 0.010 & 0.010 & 66.14 & $<0.001$ \\
Upstream channel depth & -1.110 & 0.060 & -19.84 & $<0.001$ \\
Average channel width & 0.070 & 0.010 & 10.49 & $<0.001$ \\
\hline
\end{tabular}

was a strong association between these selected variables and soil conditions $\left(r^{2}=0.96\right)$. The six significant variables were grouped into three categories: (i) check dam site characteristic, consisting only of vegetation cover; (ii) sediment volume characteristics behind check dams, including potential storage capacity and actual sediment storage; and (iii) channel dimension characteristics, taking into account channel length as well as upstream depth and width of the channel. Check dam condition was positively correlated with vegetation cover, potential storage capacity, actual sediment storage, length and average width of the sediment wedge; more specifically, check dam condition (explained by sediment retention capacity) was positively correlated with vegetation cover. In contrast, a negative relationship was found between check dam condition and depth of the upstream channel.

The analysis of the Spearman matrix indicated high correlations $(>0.73$ ) among pairs of site, check dam and channel dimension variables. In more detail, the potential storage capacity of the check dams was associated to the channel upstream depth $(r=0.86)$ and the structure sediment storage $(r=0.83)$, with these latter variables also strictly linked each other $(r=0.73)$. Also the channel downstream depth was strongly correlated $(r=0.98)$ to the mean channel width. Lower correlation levels (but always significant at $\mathrm{p}<0.05$ ) were detected among other variables, such as vegetation cover and sediment filling degree $(r=0.48)$, potential storage capacity of the check dams and all channel dimensions ( $r>0.47$ ), as well as couples of variables related to channel dimensions $(r>0.44)$ (Table 3$)$.

RDA using the explanatory variables of the three categories (vegetation cover, sediment storage volume, and channel characteristics) as influencing factors and check dam condition as the response variable, quantitatively showed that vegetation cover and channel dimensions explain 32.5 and $33.2 \%$ of the variability in check dam condition respectively. In contrast, although sediment storage characteristics also showed significantly influences on check dam conditions, the explanatory percentage was only $4.01 \%$, thus much lower than the vegetation cover and channel dimensions.

The results of the sensitivity of the channel dimensions (average channel width, channel length, downstream and upstream depth), longitudinal slope, and vegetation cover on sediment potential store capacity performed by IRA are reported in Table 4 . The larger the sensitivity of an explanatory variable, the more prominently this

Table 1

Site characteristics, sediment storage and channel dimensions for 273 check dams surveyed in the Culiacan watershed (Mexico).

\begin{tabular}{|c|c|c|c|c|c|c|c|c|c|}
\hline \multirow{2}{*}{$\begin{array}{l}\text { Check dam } \\
\text { condition } \\
\text { (number) }\end{array}$} & \multicolumn{2}{|c|}{ Site characteristics } & \multicolumn{3}{|l|}{ Check dams } & \multicolumn{4}{|c|}{ Channel dimensions } \\
\hline & $\begin{array}{l}\text { Longitudinal } \\
\text { slope (\%) }\end{array}$ & $\begin{array}{l}\text { Vegetation } \\
\text { cover }(\%)\end{array}$ & $\begin{array}{l}\text { Potential storage } \\
\text { capacity }\left(\mathrm{m}^{3}\right)\end{array}$ & $\begin{array}{l}\text { Actual sediment } \\
\text { storage }\left(\mathrm{m}^{3}\right)\end{array}$ & $\begin{array}{l}\text { Sediment } \\
\text { Filling } \\
\text { Degree (\%) }\end{array}$ & Length (m) & $\begin{array}{l}\text { Downstream } \\
\text { depth }(\mathrm{m})\end{array}$ & $\begin{array}{l}\text { Upstream }^{* * \hbar} \\
\text { depth }(m)\end{array}$ & $\begin{array}{l}\text { Average width of } \\
\text { the sediment } \\
\text { wedge }(\mathrm{m})\end{array}$ \\
\hline $\begin{array}{r}\text { Functional } \\
\left(\begin{array}{lll}1 & 1 & 6\end{array}\right)\end{array}$ & $6.66 \pm 0.57$ & $45 \pm 2$ & $77.54 \pm 7.44$ & $35.78 \pm 4.04$ & $45 \pm 0.01$ & $15.47 \pm 0.73$ & $1.14 \pm 0.02$ & $0.51 \pm 0.02$ & $6.93 \pm 0.29$ \\
\hline Filled (83) & $7.68 \pm 0.76$ & $53 \pm 3$ & 37.64 & 37.64 & 100 & $11.15 \pm 0.85$ & $0.99 \pm 0.03$ & $0.36 \pm 0.02$ & $5.49 \pm 0.28$ \\
\hline Broken (74) & $6.53 \pm 0.60$ & $13 \pm 3$ & $25.47 \pm 8.67$ & - & - & $14.62 \pm 0.97$ & $1.24 \pm 0.05$ & $0.15 \pm 0.04$ & $8.54 \pm 0.56$ \\
\hline
\end{tabular}

* Ratio of actual sediment storage to potential storage capacity.

** Measured immediately close to the check dams. 
Table 3

Spearman's correlation matrix among variables measured close to 273 check dams in Culiacan watershed (Mexico).

\begin{tabular}{|c|c|c|c|c|c|c|c|c|c|c|}
\hline \multirow[t]{2}{*}{ Variable } & & \multicolumn{2}{|c|}{ Site characteristics } & \multicolumn{3}{|c|}{ Check dams } & \multicolumn{4}{|c|}{ Channel dimensions } \\
\hline & & $\begin{array}{l}\text { Longitudinal } \\
\text { slope }\end{array}$ & $\begin{array}{l}\text { Vegetation } \\
\text { cover }\end{array}$ & $\begin{array}{l}\text { Potential } \\
\text { storage } \\
\text { capacity }\end{array}$ & $\begin{array}{l}\text { Actual } \\
\text { sediment } \\
\text { storage }\end{array}$ & $\begin{array}{l}\text { Sediment } \\
\text { Filling } \\
\text { Degree }\end{array}$ & Length & $\begin{array}{l}\text { Downstream } \\
\text { depth }\end{array}$ & $\begin{array}{l}\text { Upstream } \\
\text { depth }\end{array}$ & $\begin{array}{l}\text { Average width } \\
\text { of the } \\
\text { sediment } \\
\text { wedge }\end{array}$ \\
\hline \multirow[t]{2}{*}{ Site characteristics } & $\begin{array}{l}\text { Longitudinal } \\
\text { slope }\end{array}$ & 1 & -0.024 & 0.025 & -0.039 & 0.027 & -0.020 & -0.041 & -0.037 & -0.050 \\
\hline & Vegetation cover & & 1 & 0.209 & 0.343 & 0.484 & -0.199 & -0.138 & 0.264 & -0.170 \\
\hline \multirow[t]{3}{*}{ Check dams } & $\begin{array}{l}\text { Potential storage } \\
\text { capacity }\end{array}$ & & & 1 & 0.826 & 0.281 & 0.512 & 0.552 & 0.860 & 0.468 \\
\hline & $\begin{array}{l}\text { Actual sediment } \\
\text { storage }\end{array}$ & & & & 1 & 0.586 & 0.359 & 0.375 & 0.734 & 0.301 \\
\hline & $\begin{array}{l}\text { Sediment Filling } \\
\text { Degree }\end{array}$ & & & & & 1 & -0.200 & -0.157 & 0.380 & -0.193 \\
\hline \multirow[t]{4}{*}{ Channel dimensions } & Length & & & & & & 1 & 0.534 & 0.231 & 0.530 \\
\hline & $\begin{array}{l}\text { Downstream } \\
\text { depth }\end{array}$ & & & & & & & 1 & 0.442 & 0.977 \\
\hline & Upstream depth & & & & & & & & 1 & 0.378 \\
\hline & $\begin{array}{l}\text { Average width of } \\
\text { the sediment } \\
\text { wedge }\end{array}$ & & & & & & & & & 1 \\
\hline
\end{tabular}

variable influences the sediment retention capacity. Channel depth downstream of the check dam was found to be the most important influential variable as it is the most sensitivity parameter (136.7). The relative sensitivity of channel depth upstream of the check dam and vegetation cover are comparable to each other, although these variables are less important than the channel depth downstream of the check dam (38.1 and 20.7, respectively). Finally, the relative sensitivity of longitudinal slope, length and average width of the channel are very low and negative.

\section{Discussion}

Check dams can be an effective tool for mitigating degradation provided that they are maintained after construction. Check dam failure, which may be due to many factors, can cause scour problems and release sediment into flow downstream. This is the case of more than a half of the 273 stone check dams installed in the Culiacan watershed, which were not operating as designed just 3-5 years after their construction, due to both sedimentation and structural failure. As a matter of fact, among the structures analysed in this case study, $27 \%$ of stone check dams were damaged by water and sediment during runoff, while for $30 \%$ of the structures the sediment storage capacity was practically depleted. In the first case, it is evident that the collapsed check dams are not functioning as designed. In the second case, it is true that the check dams no longer accumulate the solid material transported by runoff; however, these structures do contribute to bed stabilisation (due to the longitudinal slope reduction) and flood attenuation (because of the wider channel section).

The investigation revealed that longitudinal channel slope behind the surveyed check dams is not noticeably different among filled, functional and broken structures. In general we might expect to see variations in slope because where intact structures act as a barrier against runoff and, when flow velocity is reduced, sediment accumulates behind the check dam thus aggrading locally its profile (Bombino et al., 2008). This unexpected result could be explained by the fact that in our check dams aggradation is localized and proximate to the structure and channel measurements just limited to points immediately behind a check dam where most of the sediment accumulates, but were deliberately made at a distance upstream of the check dams. This choice was adopted because we wanted to check whether the stabilising effects of a check dam on channel profile is localised or extends upstream of the structure, that is, far from its direct influence (as instead, revealed by Bombino et al., 2008, however in other environmental contexts). Evidently, the profile survey highlights the overall stability of channel slope, independent of check dam conditions.

Furthermore, higher vegetation cover is found in sub-watershed with functional and filled check dams, thus confirming the positive effects of check dams on vegetation development behind the structures, documented in other environments (e.g. Boix-Fayos et al., 2007; Bombino et al., 2006, 2009, 2013). Vegetation helps channel stabilisation: in-channel vegetation reduce water velocity and soil detachment, and in vegetated hillslopes water and sediment supply to the channel decrease (Keesstra et al., 2108).

From this investigation it is clear that the potential storage capacity of functional check dams is higher (by over 100\%) than filled structures, and the functional structures are located downstream of longer channels (supplying water and sediment) compared to filled check dams; conversely, the channel profile upstream of the filled check dams is steeper compared to functional structures. This finding (that is, longer channels upstream of functional check dams) partially contrasts with the results of research conducted by Li et al. (2007), who stated that check dams with a longer or steeper up-gully have a low capacity to retain soil, because soil from the upper reaches is not easily deposited by larger and more rapid flood events. In our study, the vegetation

Table 4

Sensitivity analysis of site characteristics and channel dimensions (explanatory variables, ordered by SFD) on sediment retention of check dams in the Culiacan watershed (Mexico).

\begin{tabular}{|c|c|c|c|c|c|c|}
\hline \multirow[t]{2}{*}{ Parameter } & \multicolumn{6}{|c|}{ Explanatory variables } \\
\hline & Downstream depth & Upstream depth & Vegetation cover & Longitudinal slope & Channel length & Average channel width \\
\hline Absolute Sensitivity $\left(\mathrm{S}_{\mathrm{SFD}}\right.$ ) & 1.0056 & 0.2802 & 0.1525 & -0.0377 & -0.0107 & -0.0074 \\
\hline Relative Sensitivity ( $\mathrm{s}_{\mathrm{SFD}}$ ) & 136.7 & 38.1 & 20.7 & -5.1 & -1.5 & -1.0 \\
\hline
\end{tabular}


cover associated with both filled and functional check dams (whose values are very similar) likely limits soil particle detachment and transport thereby reducing the volume of sediment available for deposition: for functional check dams this leads to a not already depleted sediment storage capacity; filled check dams, also showing a well developed vegetation cover, stores an actual sediment volume similar to functional check dams, but their potential storage capacity has not depleted.

Broken check dams retained the capacity to store accumulated sediment (although lower by about 70\% than functional check dams). In particular, sediment was stored behind non-broken side walls. The actual sediment storage is similar for functional and filled check-dams, in spite of the higher length of the channel upstream of the latter. On average, the ratio of actual to potential sediment storage of functional check dams (SFD) is close to $50 \%$, which should increase with time assuming the check dams continue to function. In the Loess Plateau, Jiao et al (2003) concluded that the ratio of the soil retained by a check dam to the total transported from the upper reaches ranged from $23.3 \%$ to $52.9 \%$, and the ratio had a positive relationship with check dam height and a negative relationship with the sub-watershed area above of the check dam.

The analysis of channel dimension characteristics grouped according to the current operating condition of check dams shows better developed sediment wedges (higher upstream depth, width and length) for functional check dams compared to filled structures. As expected, larger structures stored greater volumes of sediments and nevertheless the sediment storage capacity of these structures has not been fully depleted. It is interesting to notice that downstream of broken check dams the channel depth is higher compared to the other check dam conditions; evidently, in spite of the lower upstream depth, the local scouring on the downstream side of broken structure is high, due to the erosive power of the water stream. This phenomenon was observed extensively for the broken check dams (more than $80 \%$ ) through the presence of destroyed stones at the sides of the channel that caused a decrease in cross section area.

The construction of multi-regression models between the check dam conditions and factors (linked to site location, sediment storage and channel dimension characteristics) highlights that only six of the potentially influencing variables considered have a significant impact on check dam conditions. Moreover, of these six causal factors, vegetation cover and channel dimensions were found to be the most influential ones (see results of redundancy analysis, explaining more than $65 \%$ of the variability of the check dam conditions). Overall, channel dimension was the most important factor determining check dam condition, followed by vegetation cover.

The negative correlation between check dam condition and upstream channel depth leads one to think that taller structures are most likely to be exposed to failure risk, because of the soil bank strains behind check dams of non-embedded building material. Conversely, sediment wedges behind check dams with lower height, but with overall larger widths lengths appear to be more stable, given comparable retained sediment volumes. Finally, the actual sediment storage appears to be the most influential variable on check dam conditions.

It has been highlighted in the literature (e.g. Conesa Garcia and Garcia Lorenzo, 2010; Ramos-Diez et al., 2017b) that a large number of factors influence sediment storage capacity behind check dams. This study showed that, within the Culiacan watershed, sediment retention of check dams is related to both the downstream and upstream depths of the structure and thus the height of the check dam is important. This result is expected because the structures with greater height are associated with two predominant processes: (i) local scouring downstream of the check dam, which increases and thus mobilises more sediment to be transported downstream; (ii) aggradation of channel bed upstream of check dam, forming long and wide sediment wedges, in which large volumes of sediment are stored during flooding events. However, in our study, the sensitivity analysis has highlighted that the magnitude of the second process is noticeably lower than scouring action downstream, as shown by the values of $S_{\mathrm{SFD}}$ (136.7 for downstream depth against 38.1 for upstream height of the check dam). Moreover, the performed analysis confirms the importance of vegetation cover on reducing sediment loads and thus extending the life of check dams by retaining potential storage capacity. As a matter of fact, in areas with low vegetation cover (both in the channel and in the hillslopes) the channel bed surface remains exposed to stream erosion, which mobilises sediments along the reach (as reported above). Finally, the other factors analysed (channel profile slope, length and width) were found to affect by a much lesser extent potential storage capacity, except for channel depth measured upstream of check dams (thus confirming the influence of sediment storage). This also implies that a smaller increase in the above conditions will result in a smaller decrease of the potential storage capacity.

Although the lack of influence of channel profile slope on potential storage capacity may be explained by its low variability mentioned above, the substantial independence of potential storage capacity on channel length and width is less expected. From a deeper analysis of morphological data of the individual check dams, we noticed that for the majority of the structures channel length and width do not follow a corresponding trend; in other words, often-wider check dams are not associated to longer reaches, which leads to a substantial balance between these explanatory variables. The results of our study are in contrast with findings of Zema et al. (2014), who found that the ability to retain sediment and channel local scouring downstream is linked. However, it should be noted that in the Zema et al. (2014) study, structure spacing, geomorphic conditions, and hydrologic regime where different than our study.

This research confirms that is necessary to apply an integrated approach to solve the problems of watershed soil conservation, since the factors governing the related processes - in particular in streams regulated by check dams - are numerous and of different origin. The use of check dams can be definitely useful when the sediment source is located close to or in the channel (e.g. in-channel sediment supply, channel incision, bank erosion, armour layer removal, etc.). However, where installation of check dams alone can not mitigate watershed soil degradation (particularly in hillslopes with bare soil), it is necessary to reduce sediments at the sources, preferably by enhancing the establishment of a structured and extended vegetation cover; as a matter of fact, the study has demonstrated that vegetation cover can be a prerequisite for good conditions and functioning of check dams. Overall, soil conservation and flood risk mitigation at watershed scale must be addressed by a rational and integrated combination of in-channel (such as check dams) and extensive (for instance, afforestation and terracing) actions.

\section{Conclusions}

A quantitative analysis to understand the relation between subwatershed characteristics (vegetation cover, sediment storage capacity and channel dimensions) and check dam conditions and effectiveness was carried out in a large Mexican watershed. In this regulated watershed 273 stone control structures were recently built; the factors mostly influencing their functioning and conservation - with particular regard to vegetation cover - were surveyed and analysed using a combination of four analytical techniques. This study showed that the failure of check dams was associated with low vegetation cover; conversely, with a well developed vegetation cover the majority of check dams were functional or filled, in both cases not broken. Multi-regression models showed that, under the specific environmental conditions, vegetation cover and channel dimensions explain together more than $65 \%$ of the variability of the check dam conditions. Overall, channel dimension is the most important factor determining check dam condition, but a basic role is played also by vegetation cover, since this ecological factor is important for potential storage capacity. Taller structures are most likely to be exposed to failure risk, while check 
dams with lower height, but with well-developed sediment wedges and large vegetation cover, are more stable. A sensitivity analysis showed strong dependence of potential sediment storage capacity of the check dams - and therefore of their ability to retain sediment circulating in the watershed - on downstream depth of the structure. However, also upstream height of check dams and vegetation cover of the drained subwatershed are factors with a considerable influence on sediment retention processes acting behind the stone structures.

Overall, this study has provided a quantitative identification of the most important factors affecting the structural condition of check dams and their ability to store sediment, highlighting channel characteristics, dimensions of check dams and vegetation cover as dominant factors. One must pay attention to these factors in developing the best strategies for soil conservation at the watershed scale; the role of vegetation is clear and it definitely helps for a ecologically sound management and functioning of watersheds. These findings suggest that managers: (i) consider with caution the installation of control works (such as stone or rock check dams) in sub-watershed with low vegetation cover and highly erodible soils, since here the high sediment transfer rates may increase the structure failure likelihood; (ii) adopt a larger number of small structures rather than controlling the evolution of the channel longitudinal profile by large-sized check dams, since taller structures are most likely to be exposed to failure risk, thus loosing much of their functioning.

\section{Acknowledgements}

Authors wants to thanks the collaboration of Water Works of the Centre of Sinaloa (FACES IAP). Yang Yu received the young elite scientist sponsorship program by China Association for Science and Technology (2017 to 2019). This research was also supported by IWHR Research \& Development Support Program (SE0145C082017).

We finally thank the Editor and two anonymous reviewers for their suggestions, which really help to improve the paper.

\section{References}

Allmendinger, N.E., Pizzuto, J.E., Potter, N., Johnson, T.E., Hession, W.C., 2005. The influence of riparian vegetation on stream width, eastern Pennsylvania. USA. Geol. Soc. Am. Bull. 117, 229-243.

Boix-Fayos, C., Barberá, G.G., López-Bermúdez, F., Castillo, V.M., 2007. Effects of check dams, reforestation and land-use changes on river channel morphology: case study of the Rogativa catchment (Murcia, Spain). Geomorphology 91, 103-123.

Bombino, G., Tamburino, V., Zimbone, S.M., 2006. Assessment of the effects of checkdams on riparian vegetation in the Mediterranean environment: a methodological approach and example application. Ecol. Eng. 27, 134-144.

Bombino, G., Boix-Fayos, C., Gurnell, A.M., Tamburino, V., Zema, D.A., Zimbone, S.M., 2014. Check dam influence on vegetation species diversity in mountain torrents of the Mediterranean environment. Ecohydrology 7, 678-691.

Bombino, G., Gurnell, A.M., Tamburino, V., Zema, D.A., Zimbone, S.M., 2009. Adjustments in channel form, sediment calibre and vegetation around check dams in the headwater reaches of mountain torrents, Calabria, Italy. Earth Surf. Proc. Land. 34, 1011-1021 ISSN: 0197-9337.

Bombino, G., Gurnell, A.M., Tamburino, V., Zema, D.A., Zimbone, S.M., 2007. A method for assessing channelization effects on riparian vegetation in a Mediterranean environment. River Res. Appl. 23, 613-630.

Bombino, G., Gurnell, A.M., Tamburino, V., Zema, D.A., Zimbone, S.M., 2008. Sediment size variation in torrents with check dams: effects on riparian vegetation. Ecol. Eng. 32, 166-177.

Castillo, V.M., Mosch, W.M., García, C.C., Barberá, G.G., Cano, J.N., López-Bermúdez, F., 2007. Effectiveness and geomorphological impacts of check dams for soil erosion control in a semiarid Mediterranean catchment: El Cárcavo (Murcia, Spain). Catena $70,416-427$.

Brooks, G.R., Lawrence, D.E., 1999. The drainage of the Lake reservoir and downstream geomorphic impacts along River, Saguenay area, Quebec, Canada. Geomorphology $28,141-168$

Conesa, G.C., Garcìa, L.R., 2010. Bed scouring-sedimentation balance induced by check dams in semi-arid catchments with different lithology. In: Conesa-Garcìa, C., Lenzi, M.A. (Eds.), Check Dams, Morphological Adjustments and Erosion Control in torrenTial Streams. Nova Science Publishers, New York, pp. 283-306.

Corenblit, D., Tabacchi, E., Steiger, J., Gurnell, A.M., 2007. Reciprocal interactions and adjustments between fluvial landforms and vegetation dynamics: a review of complementary approaches. Earth Sci. Rev. 84, 56-86.

Cruz, H.A., Hinojosa Guzmán, M.D., Izquierdo Marín, O.,2014. Evaluación de Obras De Retención De Azolves En El Área De Influencia De La Presa "Sanalona", En El Ejido De Imala, Municipio De Culiacán. Informe Final. Fábricas de agua del centro de Sinaloa, Universidad Autónoma Chapingo, Chapingo, México.

Food and Agriculture Organization of the United Nations/United Nations Educational, Scientific and Cultural Organization (FAO/UNESCO). 1988. Soil Map of the World. Revised Legend. World Soil Resources Report 60. Rome, Italy.

Gurnell, A.M., Petts, G.E., 2002. Island-dominated landscapes of large floodplain rivers, a European perspective. Freshwater Biol. 47, 581-600.

Gurnell, A.M., Petts, G.E., 2006. Trees as riparian engineers: the Tagliamento River. Italy. Earth Surf. Proc. Land. 31, 1558-1574.

Guyassa, E., Frankl, A., Zenebe, A., Poesen, J., Nyssen, J., 2017. Effects of check dam on runoff characteristics along gully reaches, the case of Northern Ethiopia. J. Hydrol. 545, 299-309.

Heede, B.H., 1978. Designing gully control systems for eroding watersheds. Environ. Manage. 2, 509-522.

Keesstra, S., Nunes, J., Novara, A., Finger, D., Avelar, D., Kalantari, Z., Cerdà, A., 2018. The superior effect of nature based solutions in land management for enhancing ecosystem services. Sci. Total Environ. 610, 997-1009.

Li, G.X., Li, Z.B., Wei, X., 2007. Two key physical characteristics indexes of farmland sediment for check dams in Loess Plateau. Res. Soil Water Conser. 14, 218-221 (In Chinese).

Mekonnen, M., Keesstra, S.D., Stroosnijder, L., Baartman, J.E.M., Maroulis, J., 2015. Soil conservation through sediment trapping: a review. Land Degrad. Dev. 26, 544-556.

Nichols, M.H., Polyakov, V., Nearing, M.A., Hernandez, M., 2016. Semiarid watershed response to low-tech porous rock check dams. Soil Sci. 181, 275-282.

Nyssen, J., Veyret-Picot, M., Poesen, J., Moeyersons, J., Haile, M., Deckers, J., Govers, G., 2004. The effectiveness of loose rock check dams for gully control in Tigray, northern Ethiopia. Soil Use Manage. 20, 55-64.

Pérez-García, E.A., Meave, J.A., Cevallos-Ferriz, Sergio R.S., 2012. Flora and vegetation of the seasonally dry tropics in Mexico: origin and biogeographical implications. Acta Botánica Mexicana 100, 149-193.

Polyakov, V., Nichols, M., McClaran, M., Nearing, M.A., 2014. Effect of check dams on runoff, sediment yield and retention on small semi-arid watersheds. J. Soil Water Conserv. 69, 414-421.

Quiñonero-Rubio, J.M., Nadeu, E., Boix-Fayos, C., de Vente, J., 2016. Evaluation of the effectiveness of forest restoration and check-dams to reduce catchment sediment yield. Land Degrad. Dev. 27, 1018-1031.

Ramos-Diez, I., Navarro-Hevia, J., Fernández, R.S.M., Díaz-Gutiérrez, V., Mongil-Manso, J., 2016a. Analysis of methods to determine the sediment retained by check dams and to estimate erosion rates in badlands. Environ. Monit. Assess. 188, 1-14.

Ramos-Diez, I., Navarro-Hevia, J., Fernández, R.S.M., Díaz-Gutiérrez, V., Mongil-Manso, J., 2016b. Geometric models for measuring sediment wedge volume in retention check dams. Water Environ. J. 30, 119-127.

Ramos-Diez, I., Navarro-Hevia, J., Fernández, R.S.M., Díaz-Gutiérrez, V., Mongil-Manso, J., 2017a. Evaluating methods to quantify sediment volumes trapped behind check dams, Saldaña badlands (Spain). Int. J. Sediment Res. 32, 1-11.

Ramos-Diez, I., Navarro-Hevia, J., Fernández, R.S.M., Díaz-Gutiérrez, V., Mongil-Manso, J., 2017b. Final analysis of the accuracy and precision of methods to calculate the sediment retained by check dams. Dev Land Degrad. https://doi.org/10.1002/ldr. 2778.

R Core Team, 2013. R: A language and environment for statistical computing. $\mathrm{R}$ Foundation for Statistical Computing, Vienna, Austria. URL: < http://www.Rproject.org/ $>$.

Wang, H.W., Shih, S.S., Yang, S.C., 2009. Where will all the sediments go? Impressions from Balin Dam Failure in Taiwan. In: The 4th International Yellow River Forum, October 20-23, 2009, Zhengzhou, China.

Xu, X.Z., Zhang, H.W., Zhang, O.Y., 2004. Development of check-dam systems in gullies on the Loess Plateau. China. Environ. Sci. Policy 7, 79-86.

Xu, X.Z., Liu, Z.Y., Xiao, P.Q., Guo, W.Z., Zhang, H.W., Zhao, C., Yan, Q., 2015. Gravity erosion on the steep loess slope: Behavior, trigger and sensitivity. Catena 135, 231-239.

Xu, X.Z., Li, M.J., Liu, B., Kuang, S.F., Xu, S.G., 2012. Quantifying the effects of conservation practices on soil, water, and nutrients in the Loess Mesa Ravine Region of the Loess Plateau. China. Environ. Manag. 49, 1092-1102.

Zema, D.A., Bombino, G., Boix-Fayos, C., Zimbone, S.M., Fortugno, D., 2014. Evaluation and modelling of erosion and sedimentation around check dams in a Mediterranean torrent (Calabria, Southern Italy). J. Soil Water Conserv. 69, 316-329.

Zema, D.A., Bombino, G., Denisi, P., Lucas-Borja, M.E., Zimbone, S.M., 2018. Evaluating the effects of check dams on channel geometry, bed sediment size and riparian vegetation in Mediterranean mountain torrents. Sci. Total Environ. 642, 327-340. 